\title{
Occurrence of staphylococcus aureus and its toxins in cheeses from the region of Andalusia, Spain
}

\begin{abstract}
Staphylococcus aureus is the main contaminant pathogenic agent in fresh artisanal cheeses. The main objectives of this work have been to verify the occurrence of Staphylococcus aureus in 23different artisanal cheeses of Andalusia (Spain), to detect the toxins SEs A to E by the use of VIDAS system directly from cheeses, and to identify by PCR the occurrence of the SEs (types A to D) genes, as well as the toxic shock syndrome toxin (TSST)-1 gen from the strains isolated from cheeses. The results show that of the 24cheeses analyzed in $19(80 \%)$ was positive to Staphylococcus coagulase positive, with five (20\%) negative in the isolation. Coagulase positive staphylococcal counts were less than $10^{5} \mathrm{CFU} / \mathrm{g}$. Of the 19 strains positives, were confirmed by biochemical tests such as Staphylococcus aureus. In the automated imunoenzymatic qualitative detection of enterotoxins all the cheese samples analyzed were negative. In PCR made for the identification of genes of the toxins Sea, Seb, Sec, Sed and TSST were positive four samples for the Sec gene. We can believe that the amount of Staphylococcus aureus in the cheeses was insufficient for the formation of the enterotoxins. The presence of genetically viable Staphylococcus aureus for the formation of enterotoxins demonstrates the importance of compliance with desirable quality criteria and the adoption of appropriate hygiene practices in the processing of raw materials in cheese factories to obtain a safe final product.
\end{abstract}

Keywords: artisanal cheeses, food security, PCR, staphylococcal toxins, VIDAS
Volume 8 Issue I - 2019

\author{
Medeiros MIM,' Nader Filho A, ${ }^{2}$ Jordano ${ }^{3}{ }^{3}$ \\ Ruz V, ${ }^{3}$ Medina LM, ${ }^{3}$ García Viejo F ${ }^{4}$ \\ 'Regional Center-West Pole of Research - APTA/SAA Bauru - \\ SP, Brasil \\ ${ }^{2}$ Department of Preventive Veterinary Medicine- FCAV/UNESP \\ Campus Jaboticabal - SP, Brasil \\ ${ }^{3}$ Department of Food Science and Technology, University of \\ Córdoba, Campus of Rabanales, Spain \\ ${ }^{4}$ Health Public Laboratory, Delegación Provincial de Salud, Spain
}

Correspondence: Medeiros MIM, Regional Center-West Pole of Research - APTA/SAA Bauru - SP, PDEE Proceso 0042-10-2

Capes - MEC, Brasil, Email belvt@uol.com.br

Received: July 20, 2018 | Published: January 18, 2019

\section{Introduction}

Andalusia is a wide region at the South of Spain, which traditionally has appreciable cheese consumption, including goat milk cheeses. More than a half of the goat milk production in Spain is concentrated in Andalusia. In different areas of this region goats and sheeps live together and goat and ewe milk cheeses, as well as mixed milk cheeses are produced. ${ }^{1}$ It is known that foods have a risk of microbial contamination which level varies according to their characteristics. The highest risk levels include foods of animal origin in which their elaboration and treatment conditions are uncertain. Cheeses made from non pasteurized milk have both risk factors, and are involved in most of the outbreaks reported in relation with staphylococcal enterotoxins. ${ }^{2}$ The occurrence of Staphylococcus aureus in breast infections, sometimes not recognized ${ }^{3,4}$ and in the food companies have important implications in Public Health. Milk pasteurization kills Staphylococcus aureus, but not their enterotoxins previously synthesized, which remain in foods with activity for long periods. ${ }^{5}$ As milk is indispensable for the production of cheese, it is essential to guarantee a high quality in its processing conditions. In fact, the occurrence of Staphylococcus in foods is considered as an indicator of hygienic deficiencies, mainly due to manipulation. ${ }^{6}$ Furthermore, the recontamination during the processing can be an important factor for the final quality of the product, above all in maturated/ripened cheeses. Staphylococcus is an agent responsible of an appreciable percentage of food outbreaks all over the world. Even a lot of outbreaks not diagnosed could be caused by other staphylococci, coagulase positive or negative, or other toxins different to the classical ones. ${ }^{7,8}$ Different references reported the occurrence of enterotoxigenic Staphylococcus aureus in hands, mouth and faeces of asymptomatic carriers. ${ }^{9,10}$ The economic importance of staphylococcal food poisoning has been also highlighted. ${ }^{11}$ Staphylococcus aureus secretes different factors including various enzymes, cytotoxins, exotoxins, and exfoliative toxins. Among the other secreted factors are exotoxins that include staphylococcal enterotoxins, and toxic shock syndrome toxin (TSST)$1 .{ }^{12}$ Argudin et al. ${ }^{13}$ consider that Staphylococcus aureus produces a wide variety of staphylococcal enterotoxins (SEs) and staphylococcallike (SEl) proteins. SEs and SEls have been traditionally subdivided into classical (SEA to SEE) and new (SEG to SElU2) types. These toxins can produce food outbreaks as well as allergic reactions, and also multisystem disorders, even lethal for different segments of the population. ${ }^{14,15}$ SEA, either alone or together with other SEs/SEls, is the enterotoxin most commonly reported in foods, and is also considered as the main cause of staphylococcal food outbreaks, probably due to its extraordinarily high resistance to proteolytic enzymes. ${ }^{16,17}$ To detect the sea gene in Staphylococcus aureus is very important because SEA has toxicity in low concentrations..$^{18}$ Immunoenzymatic methods, which allow the detection of staphylococcal enterotoxins, find a proper application by the use of VIDAS system, based on ELFA-Enzyme linked Fluorescent Assay. In the other hand, molecular techniques are important tools to genetically identify staphylococcal toxins. According to Priego et al., ${ }^{19}$ PCR and VIDAS system are compatible and complementary. VIDAS system detects specifically staphylococcal enterotoxins directly from food, while PCR can be used to detect the specific genes which encode the toxins of the Staphylococcus aureus isolated. The main objectives of this work have been: To verify the occurrence of Staphylococcus aureus in 24different artisanal cheeses of Andalusia, to detect SEs A to E by the use of VIDAS system directly from cheeses, and to identify by PCR the occurrence of the SEs (types A to D) genes, as well as the toxic shock syndrome toxin (TSST)-1 gen from the strains isolated from cheeses. 


\section{Material and methods}

\section{i. Sampling, isolation and biochemical identification of Staphylococcus aureus}

The occurrence of Staphylococcus aureus and its toxins was investigated in 24 artisanal cheeses: eight goat milk cheeses, eight ewe milk cheeses and eight mixed milk cheeses, all of them elaborated in Andalusia. The cheeses were obtained directly from the grocery and aseptically transported to the laboratory. All the samples were homogenized, and appropriate dilutions were prepared. Samples were cultured in duplicate on to Baird Parker agar with egg yolk tellurite and incubated at $37^{\circ} \mathrm{C}$ for $48 \mathrm{~h}$. The catalase and coagulase tests were carried out for cocci Gram positive colonies. The typical colonies were confirmed as Staphylococcus aureus using "API Staph" test and APILab Plus database (bioMérieux S.A.-France).

\section{ii. Detection of enterotoxins in cheeses}

SEA, SEB, SEC, SED and SEE enterotoxins qualitative automated immunoenzymatic detection of the samples of cheeses were carried out through ELFA (Enzyme Link Fluorescent Assay) using VIDAS (Vitek 136 Immunodiagnostic Assay System) device. 25g of each sample were added with $40 \mathrm{~mL}$ of distilled water previously incubated at $38^{\circ} \mathrm{C} \pm 2^{\circ} \mathrm{C}$ and homogenized. After $30 \mathrm{~min}$ at $18-25^{\circ} \mathrm{C} \mathrm{pH}$ was adjusted to 3.5-4.0 using $\mathrm{HCl} 5 \mathrm{~N}$. Later, a centrifugation at 3000$5000 \mathrm{~g}$ and $18-25^{\circ} \mathrm{C}$ for $15 \mathrm{~min}$ was carried out. $\mathrm{pH}$ of supernatant was adjusted to 7.5-8.0 using $\mathrm{NaOH} 1 \mathrm{~N}$. If necessary, a new centrifugation and filtering were done. $500 \mu \mathrm{l}$ were transfer to VIDAS SET2 to run test, which performs for $80 \mathrm{~min}$.

iii. SEA, SEB, SEC, SED enterotoxins and toxic shock syndrome toxin (TSST-1) genes detection

DNA was extracted from pure bacterial cultures isolated with a RTP Spin Bacteria DNA kit (Invitek, Berlin, Germany) ${ }^{16,20}$ and stored at $-20^{\circ} \mathrm{C}$ in order to further amplification of the encoding genes sequences of SEA, SEB, SEC and SED enterotoxins and toxic shock syndrome toxin (TSST-1). The detection protocol followed was according to Cunha et al., ${ }^{21}$ and Johnson et al., ${ }^{22}$ using $20 \mathrm{pmol}$ of each oligonucleotide primer:

Sea1 ( 5 ' -TTG GAA ACG GTT AAA ACG AA) and Sea2 (5'-GAA CCT TCC CAT CAA AAA CA);

Seb1 (5'-TCG CAT CAA ACT GAC AAA C) and Seb2 (5'-GCA GGT ACT CTA TAA GTG CC);

Sec1 (5'-GAC ATA AAA GCT AGG AAT TT) and Sec2 (5'-AAA TCG GAT TAA CAT TAT CC);

Sed1 (5'-CTA GTT TGG TAA TAT CTC CT) and Sed2 (5'-TAA TGC TAT ATC TTA TAG GG);

Tst1 (5'-ATG GCA GCA TCA GCT TGA TA) and Tst2 (5'-TTT CCA ATA ACC ACC CGT TT) and 0.5 U of Taq polimerase for amplification host-start type

Five $\mu$ of DNA of each strain genetically identified as Staphylococcus aureus were used. For the PCR, the thermal cycle run conditions were: First cycle of denaturation at $94^{\circ} \mathrm{C}$ for $4 \mathrm{~min}$, annealing step at $55^{\circ} \mathrm{C}$ for $1.5 \mathrm{~min}$, and elongation step at $72^{\circ} \mathrm{C}$ for $1.5 \mathrm{~min}$. A second cycle used $94^{\circ} \mathrm{C}$ for $2 \mathrm{~min}$, annealing step at $53^{\circ} \mathrm{C}$ for $1.5 \mathrm{~min}$, and elongation step at $72^{\circ} \mathrm{C}$ for $1.5 \mathrm{~min}$. The third cycle was performed reducing the annealing temperature to $51^{\circ} \mathrm{C}$, followed by 37 cycles of $94^{\circ} \mathrm{C}$ for $2 \mathrm{~min}, 51^{\circ} \mathrm{C}$ for $1.5 \mathrm{~min}$ and $72^{\circ} \mathrm{C}$ for $1.5 \mathrm{~min}$. After these 40 cycles the tubes were incubated at $72^{\circ} \mathrm{C}$ for $7 \mathrm{~min}$ and stored at $4^{\circ} \mathrm{C}$ up to the final of the process. The PCR amplified products were separated by electrophoresis at $150 \mathrm{~V}$ for $1.5 \mathrm{~h}$ through agarose gel ( $2 \%$ ethidium bromide), visualized under UV light and compared to markers of $100 \mathrm{pb}$.

\section{Results and discussion}

The occurrence of Staphylococcus coagulase positive was detected in 19 of the 24 cheeses analyzed ( $80 \%) .100 \%$ of the Staphylococcus coagulase positive isolated were confirmed as Staphylococcus aureus. The qualitative immunoenzymatic detection showed the absence of enterotoxins production in all 19 cheeses studied Staphylococcus aureus positive, even in those with counts higher than $5 \mathrm{log} \mathrm{ufc} / \mathrm{g}$ (30\% of the cheeses), which exceed the EC Regulation. ${ }^{2}$ One of those cheeses was elaborated from pasteurized milk. This is an evidence of crossing contamination during the processing and/or handling deficiencies. Our results are even lower than those obtained by Sampaio and Nader Filho ${ }^{23}$ in Brazilian cheeses (Mato Grosso) where a $50 \%$ of the samples showed bacterial counts higher than those allowed by their legislation. Regarding to the identification of enterotoxins encoding genes, four cheeses $(21 \%)$ were positive to sec gen Figure 1, the only SE gen detected. It is prevalence lower than that found by Arcuri et al., ${ }^{24}$ in which a $72.9 \%$ of Staphylococcus aureus isolated bear SEs genes. In our work sec gen was found in higher frequency in Staphylococcus aureus isolated from cheeses elaborated from raw milk. This fact agrees with Hunt et al., ${ }^{25}$ who reported on raw milk used for raw milk cheese 26 isolations from only one supplier containing the sec gene and producing SEC, although $83.2 \%$ of the isolations did not contain the SEs genes or the toxin producing capability tested for. Scherrer et al. ${ }^{26}$ verified the occurrence of this gen in a $14.6 \%$ of the strains de Staphylococcus aureus from goat milk. Also for Kav et al., ${ }^{27}$ the most commonly toxin gen detected in white-brined Urfa cheese was sec (25\% of tested strains), as well as in the case of Akineden et al., ${ }^{28}$ from goat's milk cheese. Ostyn et al., ${ }^{29}$ obtained the occurrence of one or two toxins by ELISA test in a $77 \%$ of the cheeses studied, and SED was the toxin most frequently identified (87\%). In this last work, the occurrence of sed gen was detected by PCR in a $84.6 \%$ of the samples. Gutiérrez et al. ${ }^{30}$ reported different results, in which 11 from 20 samples (55\%) showed groth ion Baird Parker agar. Only a $20 \%$ of them were identified as Staphylococcus aureus, after coagulase test. And only a $5 \%$ produced SEA. Gücükolu et al., ${ }^{31}$ detected the presence of genes encoding the staphylococcal enterotoxins SEA, SEC, and SED from cheeses samples in Samsun province of Turkey. In our work, where staphylococcal enterotoxins were not found directly from the cheeses, PCR demonstrated to be an important tool to supply complementary information about the toxigenic potential of the material studied. In fact, Ostyn et al., ${ }^{29}$ consider the importance of molecular techniques to identify the occurrence of toxigenic strains in foods, because immunoenzymatic assay usually confirms the detection of toxins in foods with counts higher than $10^{5} \mathrm{cfu} / \mathrm{g}$. In that sense, it is plausible that the counts of Staphylococcus aureus were not enough to produce enterotoxins. Taking into account the occurrence of Staphylococcus aureus genetically viable to synthesize them, ${ }^{32}$ it is demonstrable the extremely importance of the performance of desirable quality criteria, and also to assure the proper hygiene measures and practices in the raw material processing at the cheese farms in order to guarantee the quality and safety of the final product. 


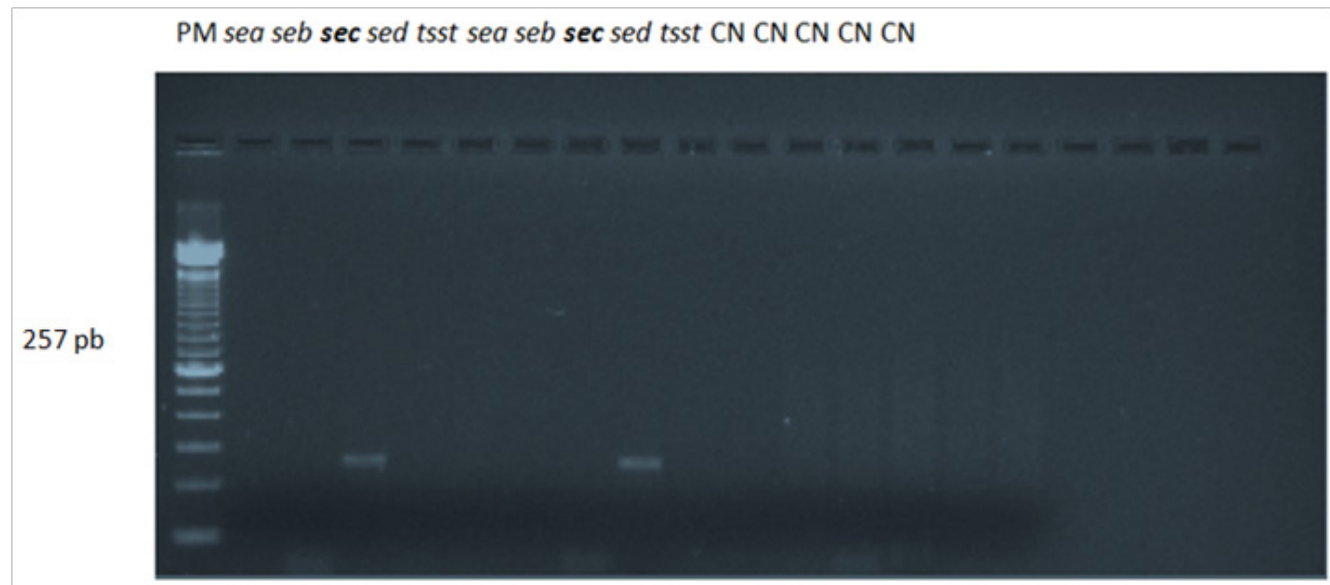

Figure I Identification of enterotoxins genes.

PM, Molecular weight size marker Ladder 100 (Invitrogen®); CN, Negative Control

\section{Acknowledgments}

None

\section{Conflicts of interest}

The author declares that there are no conflicts of interest

\section{References}

1. Silva-Pérez R. The livestock policies of the European Union. Application and applicability in Andalusia. Blas Infante Foundation and University of Huelva. 1996;467.

2. Anonymous. The Institute of Food Science and Technology. Food safety and cheese. Food Science Tech Today. 1998;12(2):117-22.

3. D'Amico DJ, Donnelly CW. Characterization of Staphylococcus aureus strains isolated from raw milk utilized in small-scale artisan cheese production. J Food Prot. 2011;74(8):1353-1358.

4. Medeiros MIM, Souza LC. Association of pathogenic agents isolated in the microbiological analysis of water, with the presence of clinical or subclinical mastitis, in dairy cows of the Cerqueira César region - SP. Science and Agrotechnology. 2009;33(2):580-585.

5. Carmo LS, Dias RS, Linardi VR, et al. Food poisoning due to enterotoxigenic strains of Staphylococcus present in Minas cheese and raw milk in Brazil. Food Microbiol. 2002;19(1):9-14.

6. González-Miret M, Coello MT,Alonso S, et al. BeefHACCP: Intervention and nonintervention systems. Food Control. 2001;66(1-2):261-268.

7. Martín MC, Fueyo JM, González-Hevia MA, et al. Genetic procedures for identification of enterotoxigenic strains of Staphylococcus aureus from three food poisoning outbreaks. Int J Food Microbiol. 2004;94(3):279-286.

8. Rosec JP, Guiraud O. Staphylococcal enterotoxin genes of classical and new types detected by PCR in France. Int J Food Microbiol. 2002;77(1-2):61-70.

9. Andrade GP, Zelante F. Simultaneous occurrence of enterotoxigenic Staphylococcus aureus on the hands and in the mouth and stools of asymptomatic carriers. Revista de Saúde pública. 1989;23(4):277-284.

10. Pereira ML, Carmo LS, Lara MA, et al. Enterotoxigenic staphylococci from food handlers working in an industrial kitchen in Belo Horizonte, MG (Brazil). Revista de Microbiologia. 1994;25(3):161-165.

11. Su YC, Wong ACL. Current perspectives on detection of staphylococcal enterotoxins. J Food Prot. 1997;60(2):195-202.
12. Pinchuk IV, Beswick EJ, Reyes VE. Staphylococcal enterotoxins. Toxins. 2010;2(8):2177-2197.

13. Argudin MA, Mendoza MC, Rodicio MR. Food poisoning and Staphylococcus aureus enterotoxins. Toxins. 2010(2):1751-1773.

14. Clemente M, das G, do Valle RHP, et al. Staphylococcus in cheeses made from raw and pasteurized milk. Food Hygiene Magazine. 2003; 17:(104-105):38-39.

15. Jarraud S, Cozon G, Vandenesch F, et al. Involvement of enterotoxins $G$ and I in staphylococcal toxic shock syndrome and staphylococcal scarlet fever. J Clin Microbiol. 1999;37(8):2446-2449.

16. Argudin MA, Fetsch A, Tenhagen BA, et al. High Heterogeneity within Methicillin-Resistant Staphylococcus aureus ST398 Isolates, Defined by Cfr9I Macrorestriction-Pulsed-Field Gel Electrophoresis Profiles and spa and SCCmec Types. Appl Environ Microbiol. 2010;76(3):652-658.

17. Balaban N, Rasooly A. Staphylococcal enterotoxins. Int J Food Microbiol. 2000;61(1):1-10.

18. Evenson ML, Hinds MW, Bernstein RS, et al. Estimation of human dose of Staphylococcal enterotoxin A from a large outbreak of staphylococcal food poisoning involving chocolate milk. Int J Food Microbiol. 1988;7(4):311-316.

19. Priego R, Medina LM, Jordano R. Comparison between the Vitek Immunodiagnostic Assay System and PCR for the Detection of Pathogenic Microorganisms in an Experimental Dry Sausage during Its Curing Process. J Food Prot. 2009;72(9):1977-1981.

20. Imirzalioglu C, Dahmen H, Hain T, et al. Highly Specific and Quick Detection of Mycobacterium avium subsp. paratuberculosis in feces and gut tissue of cattle and humans by Multiple Real Time PCR Assays. $J$ Clin Microbiol. 2011;49(5):1843-1852.

21. Cunha Maria LRS, Calsolari RAO, Araújo Junior JP. Detection of enterotoxin and Toxic Shock Syndrome Toxin 1 genes in Staphylococcus, with emphasis on coagulase-negative Staphylococci. Microbiol Immunol. 2007;51(4):381-390.

22. Johnson WM, Tyler SD, Ewan EP, et al. Detection of genes for enterotoxins, exfoliative toxins, and toxic shock syndrome toxin 1 in Staphylococcus aureus by the polymerase chain reaction. J Clin Microbiol. 1991;29(3):426-430.

23. Sampaio E, Nader-Filho A. Occurrence of Staphylococcus aureus in cheese made in Brazil. Rev Saúde Pública. 2000;34(6):578-580.

24. Arcuri EF, Ângelo FF, Martins Guimarães MF, et al. Toxigenic status of Staphylococcus aureus isolated from bovine raw milk and Minas frescal cheese in Brazil. J Food Prot. 2010;73(12):2225-2231. 
25. Hunt K, Schelin J, Rådström $P$, et al. Classical enterotoxins of coagulase-positive Staphylococcus aureus isolates from raw milk and products for raw milk cheese production in Ireland. Dairy Sci Technol. 2012;92(5):487-499.

26. Scherrer D, Corti S, Muehlherr JE, et al. Phenotypic and genotypic characteristics of Staphylococcus aureus isolates from raw bulk-tank milk samples of goats and sheep. Vet Microbiol. 2004;101(2):101-107.

27. Kav K, Col R,Ardic M. Characterization of Staphylococcus aureus isolates from white-brined Urfa cheese. J Food Prot. 2011;74(11):1788-1796.

28. Akineden Ö, Hassan AA, Schneider E, et al. Enterotoxigenic properties of Staphylococcus aureus isolated from goats' milk cheese. Int J Food Microbio. 2008;124(2):211-216.
29. Ostyn A, de Buyser L, Guillier F, et al. Benefits of the Combined Use of Immunological-and PCR-Bases Methods for Determination of Staphylococcal Enterotoxin Food Safety Criteria in Cheeses. Food Anal Methods. 2012;5(2):173-178.

30. Gutiérrez G, Revollo S, Espada A, et al. Identificación mediante PCR del gen codificador de la enterotoxina de Staphylococcus aureus en productos lácteos. Vis cienti. 2009;1(2):56-59.

31. Gücükolu A, Onur Kevenk T, Uyanik T, et al. Detection of Enterotoxigenic Staphylococcus aureus in Raw Milk and Dairy Products by Multiplex PCR. J Food Sci. 2012;77(11):620-623.

32. Anonymous. Commission Regulation (EC) No 1441/2007 of 5 December 2007 amending Regulation (EC) $\mathrm{N}^{\circ}$ 2073/2005 on microbiological criteria for food stuffs. Official Journal of the European Union. 2007. 